\title{
Performance Analysis of Road Section and Unsignalized Intersections On Jalan Cileungsi Setu and Jalan Raya Narogong
}

\author{
Muhammad Isradi $^{1 *}$, Nandhita Aulia Tarastanty ${ }^{1}$, Widodo Budi Dermawan ${ }^{1}$, \\ Amar Mufhidin', Joewono Prasetijo \\ ${ }^{I}$ Faculty of Engineering, Mercu Buana University, Jakarta, Indonesia \\ ${ }^{2}$ Faculty of Engineering, Tun Hussein University, Malaysia \\ *Corresponding author E-mail: isradi@mercubuana.ac.id
}

Manuscript received 23 Feb 2021; revised 2 March. 2021; accepted 15 March 2021. Date of publication 2 April 2021

\begin{abstract}
The unsignalized intersection which is located in Cileungsi District, precisely on Jalan Cileungsi Setu and Jalan Raya Narogong, is a commercial area with dense economic activity and densely populated settlements. As a result of the dense activity, congestion occurs due to the large number of vehicles passing the road, especially during peak hours, namely the morning and evening. Seeing this problem, an analysis is needed that aims to determine the volume, performance of roads, and unmarked intersections as measured by capacity, degree of saturation, and level of service. In analyzing this study using the Indonesian Road Capacity Manual (MKJI) 1997 method which will determine the performance of roads and intersections without signs. The data needed in this research are primary data in the form of geometric road data, traffic volume, vehicle speed data, and side friction. As well as secondary data in the form of location maps, land use, and population data. From the results of data analysis and processing, the busiest traffic flow at the intersection occurred on Sunday, November 15, 2020 at $17.30-18.30$ WIB, the saturation degree value was 1.17 with LOS F. By doing an alternative solution, the saturation degree value was 0.68 and LOS B with placing signs are prohibited from stopping around intersections, and prohibiting the flow of traffic turning right either from the main road D to the Minor C road or from the Minor C road to the main road B. On Jalan Raya Narogong, the degree of saturation is 0.74 LOS C service, this shows that the road sections do not exceed the figure required by MKJI 1997, namely $\leq$ 0.75 .
\end{abstract}

Keywords: Unsignalized Intersections, Roads, Degree of Saturation, Service Levels.

\section{Introduction}

Bogor Regency is an area that is growing relatively fast and one of the areas in West Java which has a fairly high population. Based on projections, the total population in Bogor Regency in 2018 is 5,840,907 people, consisting of 2,983,278 male residents and 2,857,629 female residents. When compared to the population in 2017, the population of Bogor Regency experienced a population growth rate of $2.20 \%$ [2].

With the increase in population there has been a development in every sector, starting from the social, economic and cultural sectors which are marked by consumptive, productive, public services, distribution services and government, demanding an increase in transportation needs that are in harmony and balanced to support daily activities. However, another impact of the development of this sector is that there is a complex problem with traffic in Bogor Regency, namely congestion.

One of the locations in Bogor Regency which is experiencing traffic problems is in Cileungsi District, namely on Jalan Cileungsi Setu - Jalan Raya Narogong. Traffic jams and busyness often occur at roads and intersections, especially during rush hours, namely the morning and evening. The density of vehicles at the intersection can be caused because Jalan Cileungsi Setu and Jalan Raya Narogong are connecting routes between regions, and are road access to housing in Metland Transyogi, Pasar Cileungsi, Hospitals, Schools, Shopping Centers, etc.

From these observations, the density at the intersection is also influenced by the absence of traffic lights and side obstacles which also add to the problems at the intersection. From the conditions of the intersection of Jalan Cileungsi Setu and Jalan Raya Narogong that have been described, it can be seen that the intersection has quite a complex problem and it is necessary to conduct research to determine the performance of these roads and intersections. As well as looking for alternative solutions to deal with congestion at these road sections and intersections. The research location can be seen in Figure 1. 

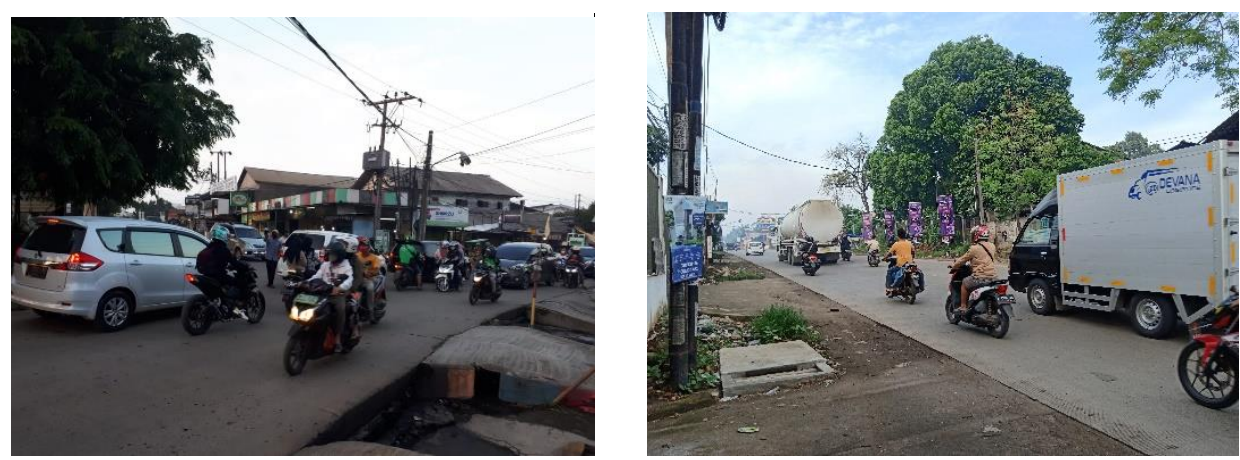

Fig 1. Research Locations for Intersections and Roads

\section{Literature Review}

Transportation in general can be defined as an effort to move, or the movement of people or goods from one location, which is called the location of origin, to another location, which is usually called the destination location, for certain purposes also use certain tools [6]. The transportation system can be interpreted as a unit of components that support each other and work together in the provision of transportation services that serve areas ranging from local (rural and urban) to national and international levels [6].

The presence of certain activity functions on land indicates that certain activities are taking place on the land in question, for example settlements, markets, tourist attractions, ports, terminals, train stations, businesses, offices, etc. All activities that take place on this land are referred to as land use. (TGL) which has the potential to cause travel flows. According to [7] predicting and estimating the number of potential travel flows arising from a land use is carried out through a 4-stage transportation planning concept, namely:

a. Travel awakening

b. Travel distribution

c. Choice of transportation mode that will be used

d. Choice of route

According to the Republic of Indonesia Law Number 38 of 2004 defines a road as land transportation infrastructure which includes all parts of the road, including complementary buildings and equipment intended for traffic, which are on ground level, above ground level, below ground level and / or water, as well as above the water level, except for railways, lorries and cable roads.

An intersection is an area where two or more roads meet, join, intersect or cross. An intersection can also be referred to as a meeting between two or more roads, either one level or not a level or a point in the road network where the roads meet and the road intersects.

\section{Methods}

Method used consists of several stages, namely the preparation stage, the data collection stage, and the data analysis stage. The preparatory stage discusses the preliminary survey carried out before the research, the data collection stage discusses data collection methods, the analysis stage discusses the processing and analysis of data carried out based on the 1997 Indonesian Road Capacity Manual (MKJI) for urban roads and unsigned intersections, and the evaluation stage for the conclusions of the study. The data used for the calculation of the performance analysis of roads and intersections without signal include primary and secondary data.

\subsection{Primary Data Primary}

Data is obtained by conducting direct surveys at the research location, including:
a. Geometric Conditions
b. Environmental Conditions
c. Traffic Data
d. Side Obstacle Data
e. Existing Speed Data

\subsection{Secondary Data}

For secondary data obtained from related agencies and self-search, secondary data required in the study include:
a. Population Data
b. Location Map
c. Land Use

\subsection{Research Time}

research was conducted for 3 (three) days, namely Monday (9 November 2020), Friday (13 November 2020) and Sunday (15 November 2020). The research was conducted for 2 hours during peak hours, namely in the morning at $06.30-08.30$, at noon at $11.30-13.30$ and in the evening at $16.30-18.30$. 


\section{Results and Discussion}

\subsection{Performance of Unsignalized Intersections}

Analysis of intersections is carried out atintersections on Jalan Cileungsi Setu and Jalan Raya Narogong. The data used are primary data in the form of geometric data, environmental data and traffic data, side friction data, and vehicle speed data obtained through direct observations and surveys at the research location. As well as secondary data obtained from related agencies.

\subsection{Geometric Data}

Intersection of Jalan Cileungsi Setu and Jalan Raya Narogong is an intersection of type 322 which means an intersection of 3 arms with 2 lanes on the minor road and 2 lanes on the main road. Existing geometric data at the intersection can be seen in table 1 and illustration of the intersection in Figure 2. Existing geometric data at the intersection include:

a. Geometric data for the main road on Jalan Cileungsi Setu (Arm D)

b. Geometric data for the minor road on Jalan Raya Narogong towards Bekasi ( Arm C)

c. Geometric data of the main road of Jalan Raya Narogong towards Bogor (Arm B)

Table 1. Existing Geometric Data of Intersection

\begin{tabular}{cccc}
\hline \multirow{2}{*}{ Description } & $\begin{array}{c}\text { of } \\
\text { Jalan Cileungsi Setu } \\
\text { Road (Arm D) }\end{array}$ & $\begin{array}{c}\text { Narogong Highway } \\
\text { towards Bekasi } \\
\text { (Arm C) }\end{array}$ & $\begin{array}{c}\text { Narogong Highway } \\
\text { towards Bogor } \\
\text { (Arm B) }\end{array}$ \\
\hline Road Type & Main & Minor & Main \\
\hline Road Type & $\begin{array}{c}2 / 2 \text { UD } \\
\text { (2 lanes 2-way } \\
\text { without separation) }\end{array}$ & $\begin{array}{c}\text { 2/2 UD } \\
\text { (2 lanes 2-way } \\
\text { without dividing) }\end{array}$ & $\begin{array}{c}\text { 2/2 UD } \\
\text { (2-lane 2-way with- } \\
\text { out dividers) }\end{array}$ \\
\hline Lane Width $(\mathrm{m})$ & 3.55 & 3.8 & 3.9 \\
\hline Road Width $(\mathrm{m})$ & $2 \times 3.55$ & $2 \times 3.8$ & $2 \times 3.9$ \\
\hline Shoulders Width $(\mathrm{m})$ & - & - & - \\
\hline Median Road Width $(\mathrm{m})$ & - & - & - \\
\hline Sidewalks Street Width $(\mathrm{m})$ & - & - & - \\
\hline
\end{tabular}

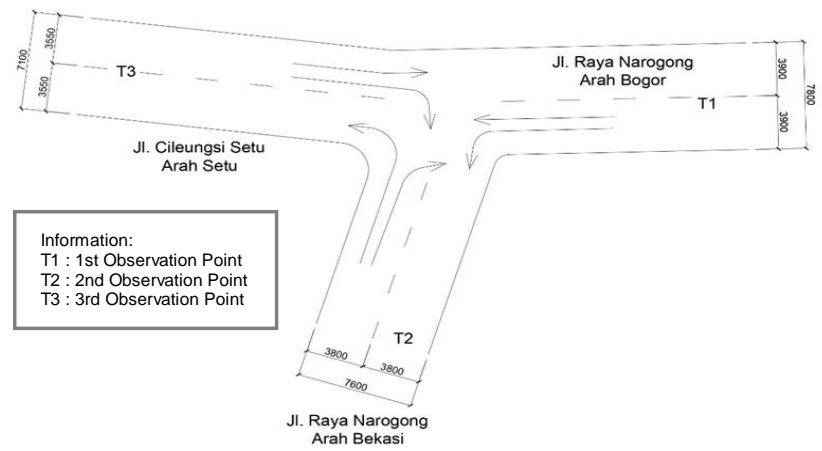

Fig 2. Illustration of Unmarked Intersection Jl. Cileungsi Setu - Jl. Raya Narogong

\subsection{Intersection Traffic Data}

Following is the intersection survey enumeration which was conducted for 2 hours in 3 days, namely Monday, Friday, and Sunday by taking morning, noon and evening. Recapitulation of Survey Results can be seen in table 2 and graphs of survey results can be seen in Figure 3.

Table 2. Recapitulation of Intersection Survey Results Monday, Friday, and Sunday

\begin{tabular}{cccc}
\hline \multirow{2}{*}{ Time } & Monday, November 9th, 2020 & Friday, 13 November 2020 & Sunday, November 15 2020 \\
\cline { 2 - 4 } & Total (pcu / hour) & Total (pcu / hour) & Total (pcu / hour) \\
\hline $06.30-07.30$ & 3549.1 & 3721.9 & 2785.8 \\
\hline $07.30-08.30$ & 3480.9 & 3728.6 & 2937.9 \\
\hline $11.30-12.30$ & 2784.3 & 2938.4 & 4015.4 \\
\hline $12.30-13.30$ & 2794.6 & 3066.3 & 4152.1 \\
\hline $16.30-17.30$ & 4492 & 4836.5 & 4837.1 \\
\hline $17.30-18.30$ & 4606.3 & 4912.6 & 5119.5 \\
\hline
\end{tabular}




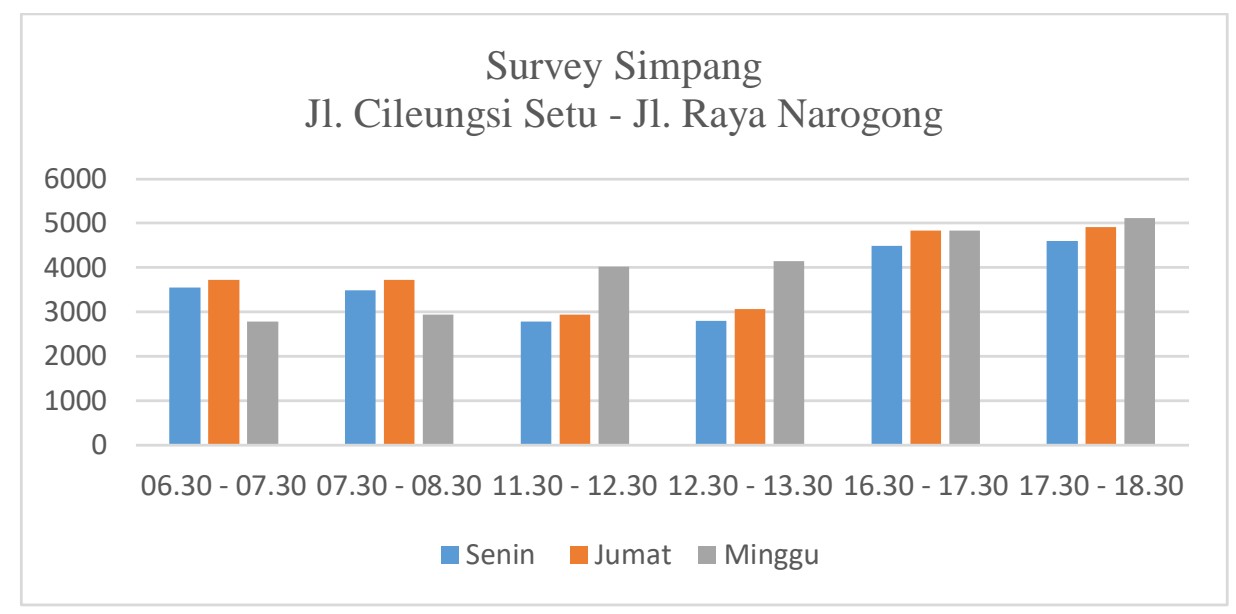

Fig 3. Graph of Intersection Survey Results for Cileungsi Setu - Jalan Raya Narogong

The busiest traffic volume occurs on Sundays and peak hours are obtained $17.30-18.30$ with Qtotal $=5119.5$ pcu / hour. This data will be used as a reference for calculating the unsignalized intersection analysis. The results of the intersection survey can be seen in table 3 .

Table 3. The results of the intersection survey for Sunday, November 15, 2020 at $17.30-18.30$

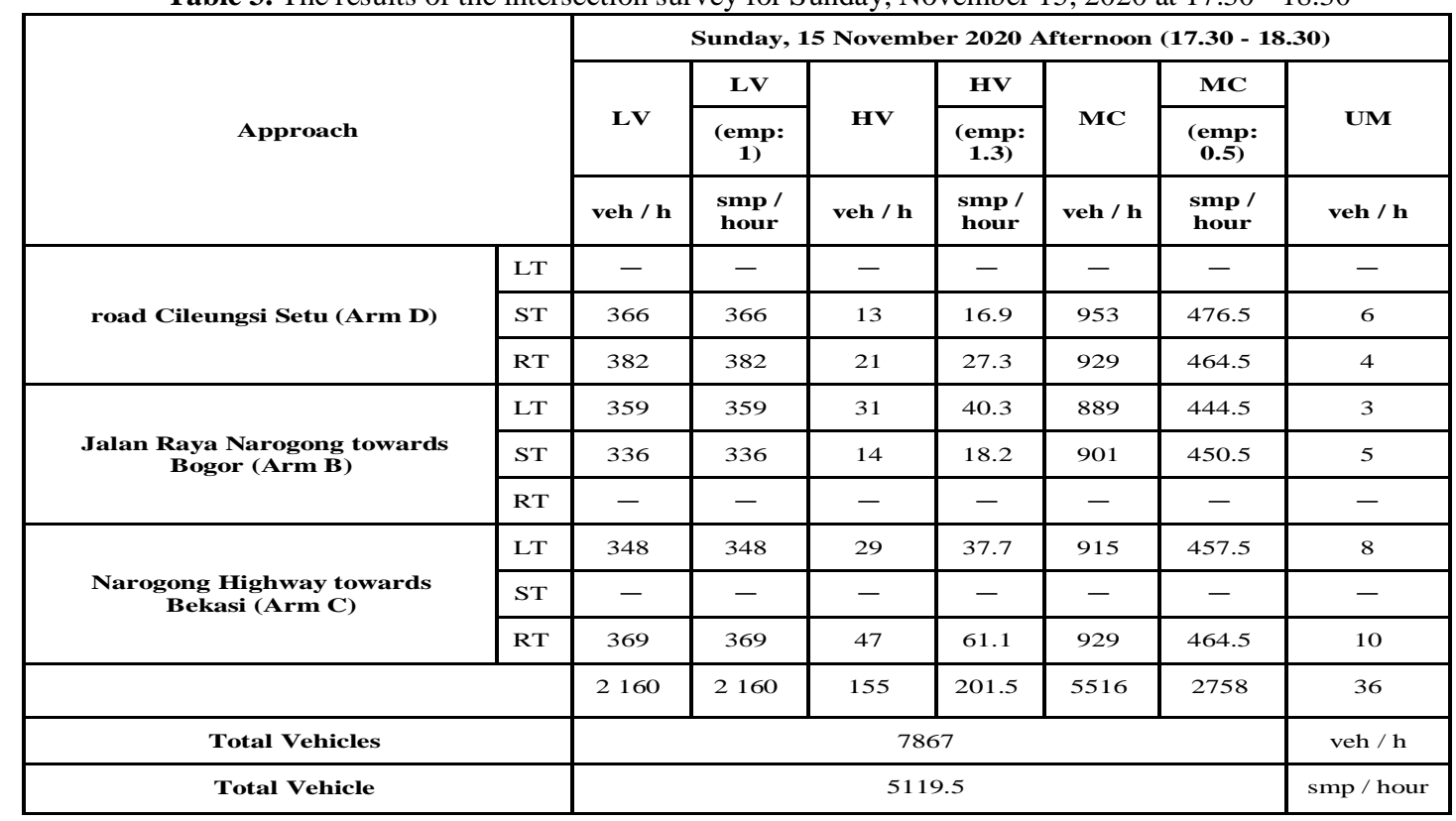

\subsection{Results of the calculation of the intersection without signal}

\section{a. Total Capacity of Unsignalized Intersection}

The total capacity for all intersection arms is the result of the multiplication of the basic capacity $\left(\mathrm{C}_{0}\right)$, namely the capacity under certain conditions (ideal) and the adjustment factors (F) taking into account the effect of field conditions on capacity. The formula for the total capacity of the unnamed intersection and the results of the intersection capacity can be seen in table 4 .

$\mathrm{C}=\mathrm{C} 0 \times \mathrm{FW} \times \mathrm{FM} \times \mathrm{FCS} \times$ FRSU $\times$ FLT $\times$ FRT $\times$ FMI

$\mathrm{C}=2700 \times 1.01 \times 1,00 \times 1.05 \times 0.86 \times 1.37 \times 1.40 \times 0.92$

$\mathrm{C}=4345.2 \mathrm{pcu} /$ hour

Table 4. Capacity for the Intersection of Jalan Cileungsi Setu and Jalan Raya Narogong

\begin{tabular}{ccccccccc}
\hline $\begin{array}{c}\text { Basic } \\
\text { Capac- } \\
\text { ity CO } \\
\text { pcu / hour }\end{array}$ & $\begin{array}{c}\text { width } \\
\text { ap- } \\
\text { proach } \\
\text { Average } \\
\text { FW }\end{array}$ & $\begin{array}{c}\text { Median } \\
\text { road } \\
\text { main } \\
\text { FM } \\
\text { City }\end{array}$ & $\begin{array}{c}\text { size } \\
\text { FCS }\end{array}$ & $\begin{array}{c}\text { Side obsta- } \\
\text { cle }\end{array}$ & $\begin{array}{c}\text { Turn } \\
\text { left } \\
\text { FLT }\end{array}$ & $\begin{array}{c}\text { Turn } \\
\text { right } \\
\text { FRT }\end{array}$ & $\begin{array}{c}\text { ratio } \\
\text { Minor / to- } \\
\text { talFMI }\end{array}$ & $\begin{array}{c}\text { Capac- } \\
\text { ity } \\
\text { pcu / hr }\end{array}$ \\
\hline$(20)$ & $(21)$ & $(22)$ & $(23)$ & $(24)$ & $(25)$ & $(26)$ & $(27)$ & $(28)$ \\
\hline 2700 & 1.01 & 1.00 & 1.05 & 0.86 & 1.37 & 1.40 & 0.92 & 4345,2 \\
\hline
\end{tabular}




\section{b. Degree of Saturation}

Degree of saturation is defined as the ratio of traffic flow to capacity, used as a major factor in determining the level of performance of intersections and road segments (MKJI 1997). The degree of saturation for all intersections, and traffic behavior can be seen in table

DS = Qsmp / C

$\mathrm{DS}=5119.5 / 4345.2$

$\mathrm{DS}=1.17$

Table 5. Traffic Behavior at the Intersection of Jalan Cileungsi Setu and Jalan Raya Narogong

\begin{tabular}{|c|c|c|c|c|c|c|c|c|c|}
\hline options & $\begin{array}{c}\text { flow } \\
\text { traffic } \\
\mathbf{Q} \\
\text { (smp / } \\
\text { hour) }\end{array}$ & $\begin{array}{l}\text { degree } \\
\text { of satura- } \\
\text { tion (DS) }\end{array}$ & $\begin{array}{c}\text { Delay } \\
\text { traffic } \\
\text { intersec- } \\
\text { tion } \\
\text { DTI }\end{array}$ & $\begin{array}{c}\text { Delay } \\
\text { traffic } \\
\text { Jl.Utama } \\
\text { DTMA }\end{array}$ & $\begin{array}{c}\text { Delay JI.Mi- } \\
\text { nor traffic } \\
\text { DTMI }\end{array}$ & $\begin{array}{l}\text { Delay } \\
\text { geometric } \\
\text { intersection } \\
\text { (DG) }\end{array}$ & $\begin{array}{l}\text { Delay } \\
\text { inter- } \\
\text { section } \\
\text { (D) }\end{array}$ & $\begin{array}{c}\text { Opportunity } \\
\text { Queue } \\
\text { (QP\%) }\end{array}$ & Goal \\
\hline 1 & 5119,5 & 1,17 & 30,10 & 18,35 & 52,96 & 4 & 34,1 & $\begin{array}{l}55,63- \\
112,47\end{array}$ & $\begin{array}{c}\mathrm{DS} \leq \\
0,75\end{array}$ \\
\hline
\end{tabular}

\section{c. Service Level}

From the results of the analysis with the Indonesian Road Capacity Manual Method (MKJI) 1997, the intersection of Jalan Cileungsi Setu and Jalan Raya Narogong has a degree of saturation of DS $=1.17$ which exceeds the target of the study, namely $\leq 0.75$ and is at the Level of Service. ClassF. Therefore, it is necessary to do an alternative solution so that the congestion at the intersection of Jalan Cileungsi Setu and Jalan Raya Narogong can be overcome.

\subsection{Alternative Solutions for Alternative Intersection}

\section{Alternative 1}

Alternative one is carried out by changing the value of the adjustment factor for the type of side obstacle road and non-motorized vehicle ( $F_{\text {RSU }}$ ) from 0.86 to 1.0, placing signs that are prohibited from stopping and controlling public transportation so that it does not stop too long around the intersection.

\section{Alternative 2}

Alternative two is to change the value of the adjustment factor for the environmental type of sideways and non-motorized vehicles (FRS) from 0.86 to 1.0, placing prohibited stop signs, and prohibiting the flow of traffic that will turn right from the minor road $\mathrm{C}$.

\section{Alternative 3}

Alternative three is by changing the value of the environmental type adjustment factor, side friction and non-motorized vehicles ( $\left.F_{R S U}\right)$ from 0.86 to 1.0 , placing prohibited stop signs, and prohibiting the flow of traffic that will turn right either from Main D road to Minor road $\mathrm{C}$ and from road Minor $\mathrm{C}$ to main road $\mathrm{B}$.

To recapitulate the results of data processing of unsigned intersections on Jalan Cileungsi Setu and Jalan Raya Narogong can be seen in table 6.

Table 6. Recapitulation of Unmarked Intersection Data Processing Results

\begin{tabular}{lcccc}
\hline \multirow{2}{*}{ Components ofIntersection Capacity } & \multicolumn{3}{c}{ Sunday Afternoon } \\
\cline { 2 - 4 } & Existing & Alternative 1 & Alternative 2 & Alternative 3 \\
\hline Intersection Type & 322 & 322 & 322 & 322 \\
\hline Capacity (Co) & 2700 & 2700 & 2700 & 2700 \\
\hline Approach Width Adjustment (Fw) & 1.01 & 1.01 & 1.01 & 1.01 \\
\hline Median Width (FM) & 1.00 & 1.00 & 1.00 & 1.00 \\
\hline City Size Adjustment (FCS) & 1.05 & 1.05 & 1.05 & 1.00 \\
\hline Side Barriers (FRSU) & 0.86 & 1.00 & 1.00 & 0.50 \\
\hline Left Turn Ratio (PLT) & 0.33 & 0.33 & 0.39 & 1.64 \\
\hline Turn Left(FLT) & 1.37 & 1.37 & 1.46 & 0 \\
\hline Turn Right Ratio (PRT) & 0.34 & 0.34 & 0.20 & 1.09 \\
\hline AdjustmentRight Turn Adjustment (FRT) & 1.40 & 1.40 & 1.27 & 0.96 \\
\hline Adjustment Minor Road Flow Ratio (FMI) & 0.92 & 0.92 & 1.00 & 4913.7 \\
\hline Intersection Capacity (pcu / hour) & 4345.2 & 5052.5 & 5309.2 & 3224.9 \\
\hline Traffic Flow (pcu / hour) & 5119.5 & 5119.5 & \\
\hline
\end{tabular}




\begin{tabular}{|c|c|c|c|c|}
\hline Degree of Saturation (DS) & 1.17 & 1.01 & 0.79 & 0.68 \\
\hline Intersection Traffic Delay (sec / junior high school) & 30.10 & 15.47 & 8.88 & 7.12 \\
\hline Major Traffic Delay (sec / smp) & 18.35 & 10.78 & 6.54 & 5.3 \\
\hline Minor Traffic Delay (sec / smp) & 52.96 & 24.59 & 18.26 & 12.53 \\
\hline Intersection Geometric Delay (sec / pcu) & 4 & 4 & 4.16 & 4.16 \\
\hline Intersection Delay ( $\mathrm{sec} / \mathrm{pcu}))$ & 34.1 & 19.47 & 13.04 & 11.28 \\
\hline Chance of Queuing (\%) & $\begin{array}{r}55.63 \%- \\
112.47 \%\end{array}$ & $\begin{array}{c}40.99 \% \\
81.19 \%\end{array}$ & $\begin{array}{c}25.19 \%- \\
50.13 \%\end{array}$ & $\begin{array}{c}18.98 \%- \\
38.78 \%\end{array}$ \\
\hline Target LOS & $\mathrm{F}$ & $\mathrm{F}$ & $\mathrm{C}$ & $\mathrm{B}$ \\
\hline
\end{tabular}

\subsection{Performance Roads}

Analysis ofAnalysis of roads in Do this on the main road, namely Jalan Raya Narogong, using standard tables described in the 1997 Indonesian Road Capacity Manual (MKJI) on Urban Roads. Analysis of road data refers to data on Sundays at 17.30 - 18.30 WIB where the highest peak flow occurs.

\subsection{Road Section Geometric Data}

Geometric conditions of the road sections required for the calculation are as follows:

Road Section Name : Narogong

Highway Type of road $\quad: 2 / 2 \mathrm{UD}, 2$ lanes 2 undivided directions

Width per lane

City Size

Environmental Type

: Very Large (> 3.0 million people)

Alignment Type

: Commercial, there are markets, shops, residential areas, etc. Median

Traffic Signs

Road Markings

: None

: Flat

: No

: None

Side A

Side B

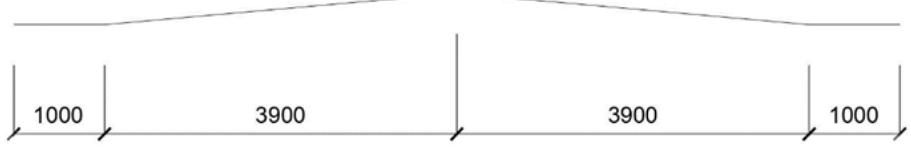

7800

Fig 4. Front View of the Road Raya Narogong

\subsection{Road Traffic Volume Data}

For road section analysis, traffic data were obtained from direct surveys at the research location for 3 days. The research was conducted on Monday, 9 November 2020, Friday, 13 November 2020 and Sunday, 15 November 2020. From the results of the occurred at Sunday, November 15 2020, 17.30 - 18.30. Graph of total flow can be seen in Figure 5.

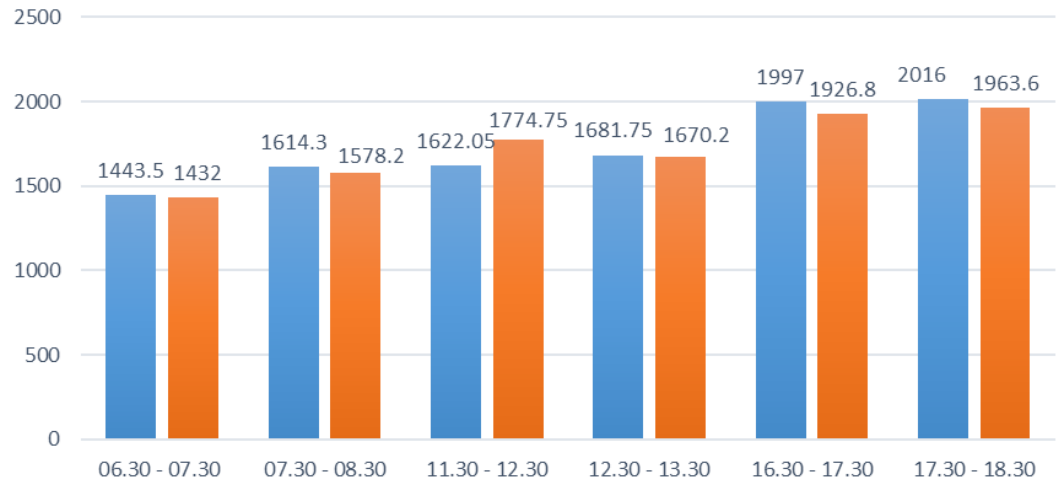

Fig 5. Graph of Total Flow on Jl. Raya Narogong on Sundays

Based on the survey results, the Narogong Highway section on Sunday, November 15, 2020, has the highest traffic in the morning, namely $1614.3 \mathrm{pcu} /$ hour on Jl. Raya Narogong heading to Cileungsi at 07.30 - 08.30, during the day at $1774.75 \mathrm{pcu} /$ hour on Jl. Raya Narogong heading to Bogor at $11.30-12.30$, and in the afternoon, $2016 \mathrm{smp} /$ hour on J1. Raya Narogong heading towards Cileungsi at 17.30 18.30. Recapitulation of volume of roads can be seen in table 7. 
Table 7. Recapitulation of Volume of Roads Used

\begin{tabular}{ccccc}
\hline \multirow{2}{*}{ Time } & \multicolumn{4}{c}{ Jl. Raya Narogong } \\
\cline { 2 - 5 } & \multicolumn{2}{c}{ Direction Cileungsi } & \multicolumn{2}{c}{ Direction Bogor } \\
\cline { 2 - 5 } & Vehicle / hour & Pcu / hour & vehicle hour & Pcu / hour \\
\hline Morning & 2814 & 1614.3 & 2747 & 1578.25 \\
\hline Noon & 2713 & 1681.75 & 2861 & 1774.75 \\
\hline Afternoon & 4219 & 2016 & 4179 & 1963.6 \\
\hline
\end{tabular}

\subsection{Calculation of Road Performance}

\section{a. Actual Speed of Roads}

To get the actual speed of vehicles on Jalan Raya Narogong, a vehicle speed survey was carried out using a speed gun. This survey was carried out along $300 \mathrm{~m}$, where the distance is part of the research survey location segment. In taking the sample the researchers took 3 samples of each type of vehicle in the form of light vehicles, heavy vehicles and motorbikes. Vehicle speed on Jalan Raya Narogong can be seen in table 8 .

Table 8. Sample Vehicle Speed

\begin{tabular}{|c|c|c|c|c|c|c|c|c|c|c|c|c|}
\hline \multirow[b]{2}{*}{ Time } & \multicolumn{6}{|c|}{ Direction Cileungsi } & \multicolumn{6}{|c|}{ Direction Bogor } \\
\hline & $\mathbf{L V}$ & $\begin{array}{c}\text { Kec. } \\
\text { Average } \\
\text { (km / } \\
\text { hour) }\end{array}$ & HV & $\begin{array}{c}\text { Kec. } \\
\text { Average } \\
\text { (km / } \\
\text { hour) }\end{array}$ & MC & $\begin{array}{c}\text { Kec. } \\
\text { Average } \\
\text { (km / } \\
\text { hour) }\end{array}$ & LV & $\begin{array}{c}\text { Kec. } \\
\text { Average } \\
\text { (km / } \\
\text { hour) }\end{array}$ & HV & $\begin{array}{c}\text { Kec. } \\
\text { Average } \\
\text { (km / } \\
\text { hour) }\end{array}$ & MC & $\begin{array}{c}\text { Kec. } \\
\text { Average } \\
\text { (km / } \\
\text { hour) }\end{array}$ \\
\hline \multirow[t]{2}{*}{ Morning } & 30 & \multirow[t]{2}{*}{30} & 19 & \multirow[t]{2}{*}{21.3} & 34 & \multirow[t]{2}{*}{31} & 27 & \multirow[t]{2}{*}{28.6} & 22 & 22.6 & 30 & \multirow[t]{2}{*}{28.6} \\
\hline & 32 & & 24 & & 29 & & 29 & & 28 & & 27 & \\
\hline Noon & 29 & 28.6 & 25 & 24.3 & 27 & 29.6 & 32 & 28 & 25 & 25 & 32 & 30 \\
\hline \multirow{3}{*}{$\begin{array}{l}\text { After- } \\
\text { noon }\end{array}$} & 26 & \multirow{3}{*}{26.3} & 24 & \multirow{3}{*}{22.6} & 32 & \multirow{3}{*}{29} & 27 & \multirow{3}{*}{27.3} & 26 & \multirow{3}{*}{23.6} & 29 & \multirow{3}{*}{29} \\
\hline & 24 & & 21 & & 29 & & 31 & & 23 & & 31 & \\
\hline & 29 & & 23 & & 26 & & 24 & & 22 & & 27 & \\
\hline
\end{tabular}

\section{b. Capacity}

Capacity can be defined as sustained traffic flow from a part of the road under certain conditions, in vehicles / hour or pcu / hour (MKJI 1997). The basic equation for determining capacity on urban roads can be seen in table 9 .

\section{$\mathrm{C}=\mathrm{C}_{\mathrm{o}} \times \mathrm{FC}_{\mathrm{W}} \times \mathrm{FC}_{S P} \times \mathrm{FC}_{S F} \times \mathrm{FCCS}$}

$\mathrm{C}=2900 \times 1.112 \times 1 \times 0.81 \times 1.04$

$\mathrm{C}=2716.5 \mathrm{pcu} /$ hour

Table 9. Capacity of Narogong Highway

\begin{tabular}{cc}
\hline Parameter Roads & Highways Narogong (2/2 UD) \\
\hline Co. & 2900 \\
\hline FCW & 1,112 \\
\hline FCSP & 1 \\
\hline FCSF & 0.81 \\
\hline FCCS & 1.04 \\
\hline C & 2716.5 \\
\hline
\end{tabular}

\section{d. Degree of Saturation}

value of the degree of saturation is used as the main factor that can determine the level of service of a road, whether the road section under study has a capacity problem or not. The degree of saturation is defined as the ratio or ratio of traffic flow to capacity. The degree of saturation is calculated using the formula below and can be seen in table 10 . 
$\mathbf{D S}=\mathbf{Q} / \mathbf{C}$

$\mathrm{DS}=2016 / 2716.5$

$\mathrm{DS}=0.74$

Table 10. Degree of saturation of Narogong Highway

\begin{tabular}{ccccc}
\hline Roads & Time & Traffic Volume (Q) & Road Capacity (C) & $\begin{array}{c}\text { Degree of } \\
\text { Saturation }\end{array}$ \\
\hline Highway & Morning & 1614.3 & 2716.5 & 0.59 \\
\cline { 2 - 5 } Narogong & Noon & 1681.75 & 2716.5 & 0.61 \\
\cline { 2 - 5 } & Afternoon & 2016 & 2716.5 & 0.74 \\
\cline { 2 - 5 }
\end{tabular}

\section{e. Service Level}

The Indonesian Road Capacity Manual (MKJI. 1997) defines the level of service (LOS) of a road segment as a qualitative measure that reflects the driver's perception of the quality of driving a vehicle. Service level value refers to DS. The level of road service can be seen in table 11 .

Table 11. Service Levels of Jalan Raya Narogong

\begin{tabular}{ccccccc}
\hline Time & $\begin{array}{c}\text { Volume } \\
\text { Traffic } \\
(\mathbf{Q})\end{array}$ & $\begin{array}{c}\text { Capacity } \\
(\mathbf{C})\end{array}$ & $\begin{array}{c}\text { Free } \\
\text { Flow } \\
\text { Speed }\end{array}$ & $\begin{array}{c}\text { Degree of } \\
\text { Saturation } \\
(\mathbf{D S})\end{array}$ & $\begin{array}{c}\text { Average Vehicle } \\
\text { Speed (FVLv) }\end{array}$ & $\begin{array}{c}\text { Level } \\
\text { Road Service } \\
\text { (LOS) }\end{array}$ \\
\hline hour $/$ & Smp / hour & Km / hour & & Km / hour \\
\hline Morning & 1614.3 & 2176,5 & 43.01 & 0.59 & 33 & $\mathrm{~A}$ \\
\hline Noon & 1681.75 & 2176.5 & 43.01 & 0.61 & 33 & $\mathrm{~B}$ \\
\hline Afternoon & 2016 & 2176.5 & 43.01 & 0.74 & 30 & $\mathrm{C}$ \\
\hline
\end{tabular}

\section{Conclusion}

From the results of field surveys and the results of data analysis calculations that have been carried out, The following conclusions can be drawn:

1. At the unsignalized intersection at Jalan Cileungsi Setu and Jalan Raya Narogong based on the results of a survey conducted for three days, the highest volume was found on Sunday, November 15, 2020 at $17.30-18.30 \mathrm{WIB}$, indicating the volume intersection 5119.5 pcu / hour with an intersection capacity of $4345.2 \mathrm{pcu} /$ hour.

2. Based on the calculations that have been made in accordance with MKJI 1997, the value of the degree of saturation (DS) at peak hour traffic volume is 1.17 for the intersection traffic delay ( $\mathrm{DT}_{\mathrm{I}}$ ) of $30.10 \mathrm{sec} / \mathrm{pcu}$, traffic delay main road (DTMA) is $18.35 \mathrm{sec} / \mathrm{pcu}$, minor

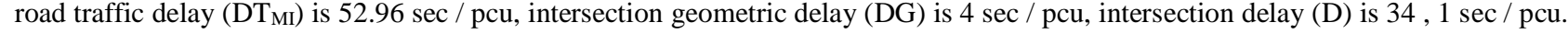
With these results, the Queuing Chance (QP\%) value is $55.63 \%-112.47 \%$. Because the DS value exceeds the target of the study, namely $\leq 0.75$ and is at the Level of Service class F, it is necessary to make alternatives to reduce the degree of saturation and delay at the intersection.

3. Of the several alternatives made, only alternative 3 gets saturation (DS) and the smallest delay is the degree of saturation (DS) of 0.68 meaning that this is included in the number required by MKJI 1997, namely $\leq 0.75$, with Intersection delay is $11.28 \mathrm{sec} / \mathrm{smp}$, and the opportunity to queue is $18.98 \%-38.78 \%$. Alternative 3 is done by changing the value of the environmental type adjustment factor, side friction and non-motorized vehicles ( $\mathrm{F}_{\mathrm{RSU}}$ ) from 0.86 to 1.0, providing a stop sign, and prohibiting the flow of traffic that will turn right from either the main road D leads to road Minor $\mathrm{C}$ or from road Minor $\mathrm{C}$ to main road $\mathrm{B}$.

4. For roads, the highest volume of vehicles is on Jalan Raya Narogong heading to Cileungsi and Bekasi which is obtained on Sunday, November 15, 2020 at $17.30-18.30$ WIB, namely $2016 \mathrm{pcu} /$ hour with a capacity of $2716.5 \mathrm{pcu} /$ hour. The degree of saturation value obtained for the performance of the Narogong Highway section at peak hours (DS) $=0.74$ with the level of service (Level of Service) C, this indicates that the road section does not exceed the figure required by MKJI 1997, namely $\leq 0,75$.

\section{References}

[1 ] Alokabel, K. (2018). Performance Analysis of Type T Unmarked Intersection in Oesapa Village, Kelapa Lima City District. III (1), 227-231.

[2] Bogor Regency Central Bureau of Statistics (2018). Bogor Regency in Figures 2019, Bogor.

[3 ] Directorate General of Highways (DJBM). 1997. Indonesian Road Capacity Manual (MKJI), Ministry of Public Works, Directorate General of Highways, Jakarta.

[4 ] Isradi, M., Dwiatmoko, H., Setiawan, MI, \& Supriyatno, D. (2020). Analysis of Capacity, Speed, and Degree of Saturation of International and Roads. Journal of Applied Science, Engineering, Technology, and Education. 
[5 ] Listiana, N., \& Sudibyo, T. (2019). Performance Analysis of the Unmarked Intersection of Jalan Raya Dramaga-Bubulak Bogor, West Java. Journal of Civil and Environmental Engineering, 4 (1), 69-78.

[6] Miro, F. 2012. Introduction to Transportation Systems. Jakarta: Erlangga Publisher.

[7 ] Miro, F. 2005. Transportation Planning for Students, Planners, and. Practitioner. Jakarta: Erlangga Publisher.

[8] Muftafif Yanuar. 2018. Traffic Unmarked Intersection and Roads Case Study at the Intersection Connecting the Tennis Court Road with Jalan Meruya Utara. Jakarta: Civil Engineering Study Program, Faculty of Engineering, Mercu Buana University.

[9] Novita Debora, Ir. Muhammad Isradi, ST, MT, IPM. 2019. Performance Evaluation of Roads and Intersections with No Signals as Efforts to Overcome Congestion on Jalan Jatiwaringin - Jalan Gamprit Raya. Jakarta: Civil Engineering Study Program, Faculty of Engineering, Mercu Buana University.

[10 ] Rorong, N., Elisabeth, L., \& Waani, JE (2015). Performance Analysis of Unmarked Intersections on Jalan S. Parman and Jalan Panjaitan. Faculty of Engineering, Department of Civil, Sam Ratulangi UniversityManado,, 3(11), 747-758.

[11 ] Rozzaq Agus. 2019. Performance Analysis of Unmarked Intersections and Roads Using the MKJI 1997 Method (Case Study of the Kemang Pratama Intersection, Jl. Raya Pekayon - Jl. Kemang Pratama Raya-Bekasi). Jakarta: Civil Engineering Study Program, Faculty of Engineering, Mercu Buana University.

[12 ] Sriharyani, L., \& Hadijah, I. (2016). The intersection performance analysis does not indicate a metro city (case study of road junctions, Jalan Sudirman, Sumbawa, Wijaya Kusuma and inspection roads). TAPAK: Construction Application Technology, 6(1), 8-14.

[13] Sudarso, SYOS (2019). Performance evaluation of unsigned intersections in the city of Madiun (case study of the Biliton intersection, the Sunaryo Compole intersection, and the Yos Sudarso intersection).

[14 ] Zain, H., Meliayana, \& Muhaimin. (2015). PERFORMANCE ANALYSIS OF THREE SINGLE IN SIGNAL (Case Study of Simpang Lamlo, Pidie District). Journal of Civil Engineering Unaya, 3(June), 422-434. 